\title{
A Healthy Park Needs Healthy Vegetation: The Story of Gorongosa National Park in the 21st Century
}

\author{
Hannah Herrero ${ }^{1, *(\mathbb{D})}$, Peter Waylen ${ }^{2}$, Jane Southworth ${ }^{2}$, Reza Khatami $\left.{ }^{2} \mathbb{(}\right)$, Di Yang ${ }^{3} \mathbb{C}$ and \\ Brian Child ${ }^{2}$ \\ 1 Department of Geography, University of Tennessee, 1000 Philip Fulmer Way, Room 315, Knoxville, \\ TN 37996-0925, USA \\ 2 Department of Geography, University of Florida, 3141 Turlington Hall, Gainesville, FL 32611, USA; \\ prwaylen@ufl.edu (P.W.); jsouthwo@ufl.edu (J.S.); seyedghkhatami@ufl.edu (R.K.); bchild@ufl.edu (B.C.) \\ 3 Mt. Natural Heritage Program, University of Montana, 1515 E. 6th Ave, Helena, MT 59620, USA; \\ di.yang@mso.umt.edu \\ * Correspondence: hherrero@utk.edu; Tel.: +1-865-974-6043
}

Received: 6 December 2019; Accepted: 29 January 2020; Published: 3 February 2020

\begin{abstract}
Understanding trends or changes in biomass and biodiversity around conservation areas in Africa is important and has economic and societal impacts on the surrounding communities. Gorongosa National Park, Mozambique was established under unique conditions due to its complex history. In this study, we used a time-series of Normalized Difference Vegetation Index (NDVI) to explore seasonal trends in biomass between 2000 and 2016. In addition, vegetation directional persistence was created. This product is derived from the seasonal NDVI time series-based analysis and represents the accumulation of directional change in NDVI relative to a fixed benchmark (2000-2004). Trends in precipitation from Climate Hazards Group InfraRed Precipitation with Station data (CHIRPS) was explored from 2000-2016. Different vegetation covers are also considered across various landscapes, including a comparison between the Lower Gorongosa (savanna), Mount Gorongosa (rainforest), and surrounding buffer zones. Important findings include a decline in precipitation over the time of study, which most likely drives the observed decrease in NDVI. In terms of vegetation persistence, Lower Gorongosa had stronger positive trends than the buffer zone, and Mount Gorongosa had higher negative persistence overall. Directional persistence also varied by vegetation type. These are valuable findings for park managers and conservationists across the world.
\end{abstract}

Keywords: remote sensing; vegetation dynamics; vegetation persistence; conservation; savannas; Africa

\section{Introduction}

Savannas are commonly defined as grassland with scattered trees, but in practice are a mix of grass, shrub, and trees [1-3] which comprise over $55 \%$ of the southern African landscape, and approximately $20 \%$ of Earth's landcover [1]. Savannas are controlled by key factors: precipitation, herbivory, fire, and humans [4-7]. Savannas are water-limited systems, therefore precipitation is the main driving factor for the ecosystem [5,8]. Up to a precipitation threshold of $750 \mathrm{~mm} /$ year, grasses dominate, between 750-950 mm/year, more mixed systems occur, and above $950 \mathrm{~mm} / \mathrm{year}$, woodlands dominate [5,7-9]. Decreases in precipitation alone can lead to declines in vegetation, and when coupled with rising temperatures the resulting lower availability of soil moisture causes even further declines in vegetation [10-12]. Savannas are an important conservation landscape in southern Africa. Understanding and conserving these systems is vital as they support high faunal and floral biodiversity. Savannas are also an important biome affecting the carbon cycle, supporting high human populations, 
and contributing $14 \%$ of global net primary productivity [8,13-17]. Conservation areas are a key resource in southern Africa both in terms of their ecological importance (biodiversity, biomass, carbon, etc.) and as socioeconomic drivers for the surrounding communities [18].

Remote sensing of these savanna systems is a challenge due to the heterogeneity of savanna landscapes, but given their ecological and socioeconomic importance, they are a target for development of innovative image analysis techniques. One such approach to evaluating savannas with imagery includes continuous time series analysis $[19,20]$. The normalized difference vegetation index (NDVI) can be used as a proxy for vegetation biomass, health, and abundance [20-26]. The value of this vegetation index may be enhanced with new time series measures to provide better understanding of trends in vegetation health over time and space [19]. One such measure, derived from NDVI, is that of vegetation persistence, which has demonstrated its usefulness in drylands globally [20]. This is an NDVI-based time series approach to compare vegetation greenness in a given season and year to a baseline period. This methodology allows the user to detect inter-annual changes of NDVI in a spatially explicit manner and identify key trends on the landscape, with a statistical significance attached to each pixel $[19,20]$.

Gorongosa National Park (GNP) in central Mozambique contains two important ecosystem types-savanna and montane rainforest. This paper examines the complex savanna system of the lower part of GNP (herein referred to as "Lower Gorongosa") and compares it to the montane rainforest of Mount Gorongosa [27]. Like many mountainous areas [28], the latter provides a haven for biodiversity much of which remains to be discovered, as evidenced by the extraordinary discoveries from the rapid biodiversity collection event held by E.O. Wilson in 2011 [29]. GNP is chosen for analysis because of the interesting conditions under which it was established and also due to the fact that it has been restored in the last decade. GNP was originally established in 1920 under Portuguese colonial rule, and the park served as headquarters for both sides at some point during both the War for Independence and the Civil War, which lasted from 1964 to 1994 . As a result, between $90 \%$ and $99 \%$ of all mammals in the park were extirpated by crossfire, lack of sustenance, and poaching, and this lack of mammals over time may affect vegetation [30]. Following peace, a variety of illegal hunting activities continued for years in the park, pressuring already drastically decreased populations. In 2004, a relationship developed between the Mozambican government and an American NGO initiating the Gorongosa Restoration Project, the first conservation collaboration of its kind in the world. This project has three main goals: science and conservation, sustainable tourism, and human development. These goals include the restoration of the ecosystem to a pre-war baseline of wildlife [31]. A significant management presence began in the park in 2008 with the aim to restock animals, which might then affect vegetation. The park is a natural experiment for the impact of herbivores on vegetation. Several studies note that the absence of large herbivores enables trees to attain maturity here in GNP, unlike other places in southern Africa where bush densification has been the trend $[32,33]$. The primary focus of restoration has been wildlife, however, a healthy park also needs healthy vegetation to sustain its wildlife populations. Therefore, the purpose of this paper is to evaluate trends in vegetation biomass during pre- (2000-2008) and post(2009-2016) management periods in GNP.

The objective of this study is to understand the trends in vegetation in Lower Gorongosa and to compare them to the buffer zone and Mount Gorongosa. The questions we addressed are: 1 . Is there a difference in the precipitation between the period since restoration management has been imposed and the prior period? 2. Has there been a trend in the seasonal precipitation time period between 2000 and 2016? 3. Can trends in vegetation density and biomass be detected in the period 2000 to 2016 ? 4 . Does the vegetation directional persistence methodology detect significant changes in NDVI as an indicator of vegetation change, in the period 2000 to 2016 ? 


\section{Materials and Methods}

\subsection{Study Area}

The GNP occupies approximately $4000 \mathrm{~km}^{2}$ in central Mozambique $\left(18.2^{\circ} \mathrm{S}\right.$ and $\left.34.0^{\circ} \mathrm{E}\right)$ (Figure 1$)$. Annual minimum and maximum temperatures on average range between $15{ }^{\circ} \mathrm{C}$ and $30{ }^{\circ} \mathrm{C}$, in the dry and wet seasons respectively. The ecosystem of the original area of the park, Lower Gorongosa (LG), is markedly different to that of the more newly incorporated Mount Gorongosa (MG), which lies to the northwest at $700 \mathrm{~m}$ elevation. Based on the park management report, LG contains various savannas ranging from "open" savanna (floodplain grassland, 21\% of LG) in the central part of the park, to "mixed" savanna (grass-shrub-open tree, 44\% of LG), and "closed" savanna (thick woodlands dominated by several different tree species, 35\% of LG). Montane rain forest vegetation dominates the flanks of MG, while short grassland/rock covers the summit. The protected area on MG is critical to the health of both LG and people living in the surrounding area, as it constitutes the dominant source of stream flow. The areas surrounding parks, known as buffer zones, provide a comparison to vegetation trends occurring inside the park because they are not as protected as parks, but have similar environmental conditions affecting them. They therefore help better understand how the park is functioning in the larger context of the landscape. Based on literature indicating that a buffer zone analysis should encompass approximately 3-4 times the size of the park [34], a $20 \mathrm{~km}$ buffer zone around the park was considered in this work. There is some limited human activity in this zone where communities live. Six study areas are addressed: (1) LG (first as a whole), and then further divided into land cover types- (2) open savanna, (3) mixed savanna, and (4) closed savanna, (5) a $20 \mathrm{~km}$ buffer zone around LG and (6) MG.

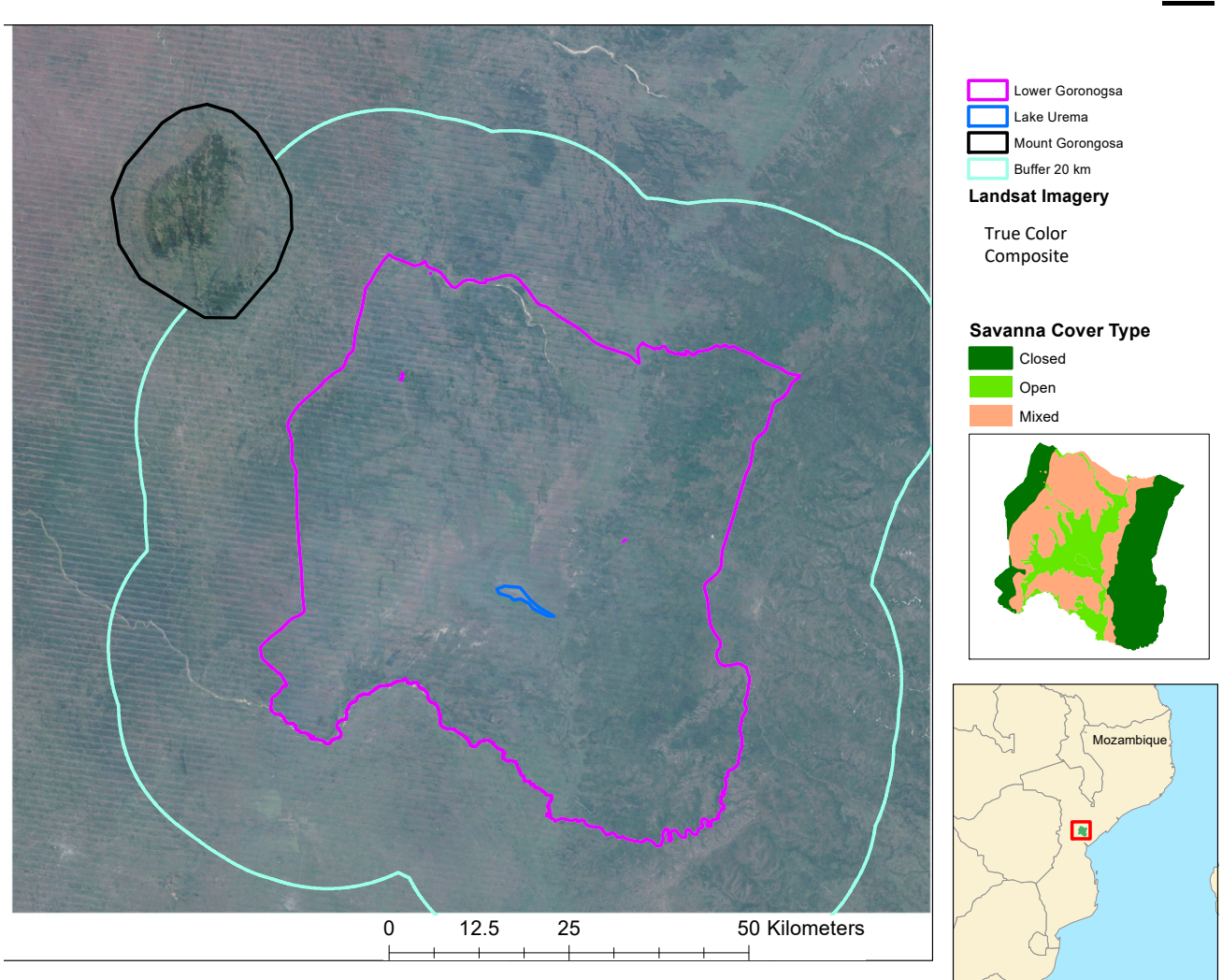

Figure 1. Study area map of low Lower Gorongosa, Mount Gorongosa and buffer area shown on a true color composite Landsat image. In the top inset map, open savanna, mixed savanna, and closed savanna are shown. 


\subsection{Vegetation Change Characteristics}

This section addresses factors used to measure vegetation change and related drivers.

\subsubsection{Mean NDVI}

The Normalized Difference Vegetation Index (NDVI) is used to establish trends in vegetation health and density over time. The metric is a band ratio between red (R) (highly absorptive in healthy vegetation) and near infrared (NIR) (highly reflective in healthy vegetation) energy [35]:

$$
N D V I=\frac{N I R-R}{N I R+R}
$$

NDVI ranges from -1 to +1 . Higher values indicate the presence of higher vegetation density, and values below 0 indicate no vegetation [35]. NDVI composite products from the Moderate Resolution Imaging Spectroradiometer (MODIS) sensor, i.e., MOD13Q1.006 Terra Vegetation Index, were used in this research due to their fine temporal resolution. The data span March 2000 to November 2016, have a spatial resolution of $250 \mathrm{~m}$, and are a 16-day composite of the highest NDVI value per pixel. The data are atmospherically corrected and masked for clouds, cloud shadows, water, and heavy aerosols. Furthermore, as water produces negative NDVI values, the Lake Urema system in LG is also masked out and removed from further analysis. Data are aggregated into seasonal composites based on per-pixel seasonal mean values for the following seasons; December, January, February (wet), March, April, May (wet), June, July, August (dry), and September, October, November (dry). Data are further aggregated by mean pixel value for the seasons into different periods corresponding to different on-the-ground management practices in GNP: 2000-2004 (no management), 2005-2008 (management contracts negotiated), 2009-2012 (beginning of on the ground management), and 2013-2016 (fully implemented on the ground management). These can be grouped broadly into 2000-2008, pre-management and 2009-2016, post-management [29]. The analysis is separated into each of the six study areas. Spatial extents of the three savanna types in LG (open, mixed, and closed) were provided by the park management team.

\subsubsection{Seasonal Precipitation Totals}

As savannas are water limited systems, monitoring trends in precipitation is critical in understanding changes in vegetation. Estimates of monthly precipitation totals from 2000 to 2016 were extracted from the Climate Hazards Group InfraRed Precipitation with Station data (CHIRPS) gridded dataset $\left(0.05^{\circ}\right.$ resolution). Given the coarse spatial resolution of the data and the relatively small study area, a mean value for each time period was extracted over the whole study area [36]. Total seasonal precipitation for the park is created for each year from the monthly estimates observations. The annual migration of the Intertropical Convergence Zone (ITCZ) is considered to be the principal driver of intra-annual precipitation [37,38]. Given the delay between the arrival of precipitation and green up of vegetation, seasonal estimates of vegetation are lagged by one month [39]. Therefore, the seasonal precipitation-vegetation pairs are respectively as follows: (NDJ-DJF; FMA-MAM; MJJ-JJA; ASO-SON). Mean annual precipitation (2000-2016) is $1075 \mathrm{~mm}$, and individual annual totals range from $665 \mathrm{~mm}$ in 2015 to $1415 \mathrm{~mm}$ in 2001.

Analysis of seasonal precipitation totals proceeds in several ways. Totals are expressed as being above or below the long-term (2000-2016) mean and the subsequent counts of the number of above/below mean years in each time period recorded. To investigate if total seasonal precipitation has increased/decreased between the two management periods, a hypergeometric test was used. The hypergeometric distribution determines the probability of experiencing a given number of years with values above (or below) mean characteristic at random [40]. It therefore highlights whether the observed number of years (above/below mean) is significantly greater than/less than, would be expected at random. Years during which a seasonal total fall above the mean are considered "successes" 
and during which it falls below the mean are considered "failures." The probability distribution of the number of successes (failures) is given as:

$$
p(x)=\frac{\left(\begin{array}{c}
k \\
x
\end{array}\right)\left(\begin{array}{c}
N-k \\
n-x
\end{array}\right)}{\left(\begin{array}{c}
N \\
n
\end{array}\right)}
$$

where $N$ is the number of years in the record (i.e., $N=17$ during 2000-2016), $n$ is the sample size (the number of years in a particular period during which a set of management practices is followed), and $k$ is the total number of observations in the entire record with the desired property (success or failure) [40]. The sample time periods for the hypergeometric distribution was chosen based on the main management time frame of 2000-2008, where there was not a management presence on the ground, and 2009-2016, where there was a heavy management presence on the ground.

Precipitation values were also graphed as a time series, normalized for seasonality, anomalies were determined, and linear trends were added. Precipitation is also quantitatively compared to mean NDVI, as savanna vegetation-precipitation association is well established [5,7-9,12,20-26].

\subsubsection{Vegetation Directional Persistence}

Newly developed directional persistence (DP), a continuous time series metric, is calculated on a per-pixel basis and is the cumulative direction of change over time in NDVI calculated in comparison to a benchmark value $[19,20]$. This approach illuminates trends in vegetation over time and space $[19,20]$. We implemented the DP analysis using the time-series data from the MOD13Q1.006 Terra Vegetation Index products outlined above in Section 2.2.1. To calculate DP, per-pixel seasonal mean NDVI over the period 2000-2004 was calculated as the benchmark. Then, all subsequent seasonal values 2005-2016 $(N=12)$ were compared to it at a pixel level, generating the equivalent of a random walk in each pixel. Under the null hypothesis of persistent vegetation, i.e., no change in vegetation, there is an equal chance of an observation above the benchmark (success) or below it (failure) [19]. For a "success" in a particular year the pixel receives a value of +1 , if a "failure", it receives a -1 . These values are accumulated through time, resulting in a net value of DP in each pixel. In the case of a $\mathrm{N}$ of 12 , a pixel value of +12 would indicate that every year had a NDVI value higher than the benchmark. Likewise, a pixel value of -12 would indicate that every year had a NDVI value lower than the benchmark. The $\mathrm{DP}$ values can be assigned to statistical significance levels based on the hypergeometric distribution. Given the preliminary nature of this exploration and the comparatively short (2005-2016) period of evaluation, a 0.10 level of significance, or critical DP of $+/-6$, is chosen for testing. The respective mean directional persistence, and the percentage of pixels returning significant (positive or negative) persistence are calculated for each of the six study areas.

\section{Results}

\subsection{Precipitation Anomolies and Trends}

Figure 2 highlights trends in seasonal precipitation, with the blue and red bars indicating the years with precipitation above and below the overall mean, respectively. Each season except ASO, returns approximately equal numbers of years above and below the long-term mean. However, it appears that there are more below-mean years later in the time series. Additionally, the magnitude of the negative anomalies are high compared to those of the positive anomalies. There were some periods of consecutive seasonal rainfall below the mean, such as in ASO from 2004 to 2010, however application of the hypergeometric test revealed no statistically significant differences at the 0.1 level in the number of positive and negative anomalies in any season or time period. This means that the number of years 
with rainfall above or below the mean were not statistically different from what we might expect at random when we compare the pre and post management periods.
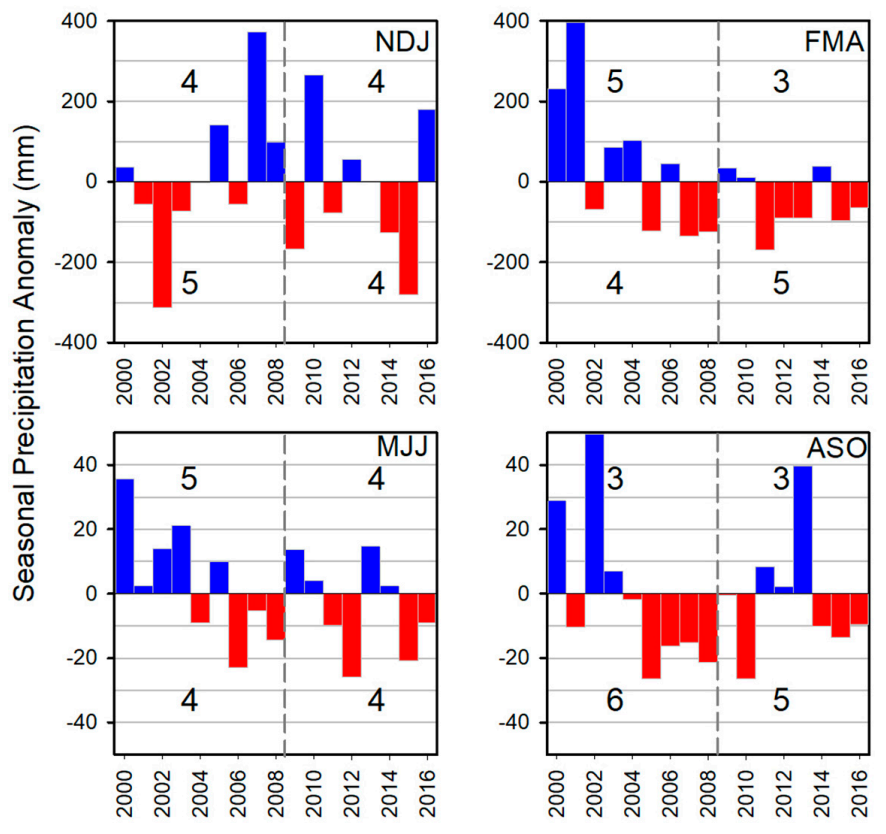

Year

Figure 2. Seasonal precipitation anomalies 2000-2016 for November, December, January (NDJ), mean 550 mm; February, March, April (FMA), mean 384 mm; May, June, July (MJJ), mean 80 mm; August, September, October (ASO), mean $61 \mathrm{~mm}$. The numbers in the graphs are count data for above and below mean precipitation years in the time period.

The time series in Figure 3 suggests a decreasing trend in precipitation over time, particularly in the latter part of the time series. In Figure 3a, when seasonal anomalies are represented by their standard deviates, there is a statistically significant decline over this time period at the 0.1 level of significance. In Figure $3 b$, where seasonal totals were separated out, there was a statistically significant decline over time in February, March, April (FMA) and May, June, July (MJJ) at the 0.05 significance level.

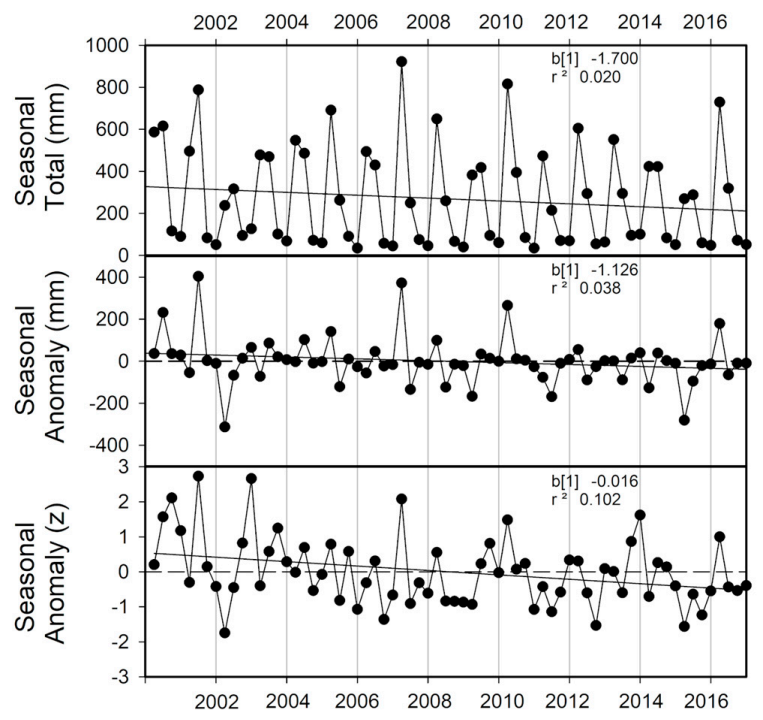

(a)

Figure 3. Cont. 


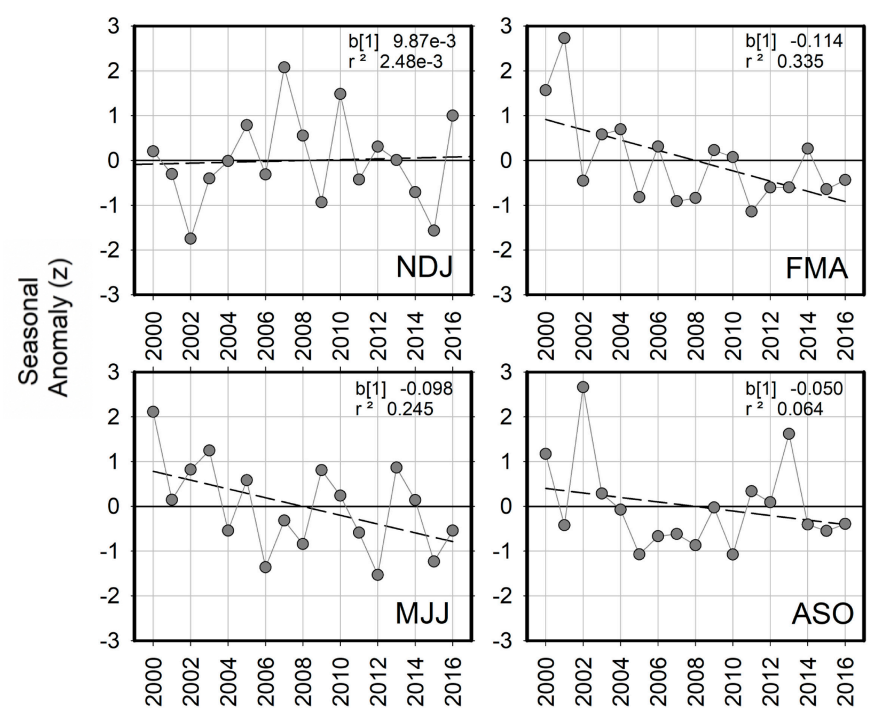

(b)

Figure 3. Precipitation time series 2000-2016 for (a) continuous raw seasonal totals, seasonal anomalies $(\mathrm{mm})$, and seasonal anomalies expressed as standard deviates $(\mathrm{z})$ and $(\mathbf{b})$ separated seasonal anomalies for November, December, January (NDJ), February, March, April (FMA), May, June, July (MJJ), and August, September, October (ASO).

\subsection{Changes of NDVI}

Mean NDVI values computed by season (MAM, JJA, SON, DJF) and time period (2000-2004, 2005-2008, 2009-2012, and 2013-2016) are mapped across the LG and MG (Figure 4). This clearly shows the role of seasonality, with higher NDVI values in the wet season than in the dry season. Even within the wet/dry seasons the impact of soil moisture accumulation (MAM is greener than DJF), and depletion (JJA is greener than SON) is apparent. Each season also appears to have some variability of NDVI during the time periods. In general, the first period (2000-2004) had the highest NDVI across the study areas, the most recent period (2013-2016) had the lowest NDVI across the study areas, and the two periods between (2005-2008 and 2009-2012) were variable.

Daily NDVI values, extracted by pixel from MODIS data from 2000-2016, are examined to give further insight into the vegetation dynamics of LG, revealing several important findings, including notable shifts in both the magnitude and timing of anomalies in each period (Figure 5a). There was an overall decline in dry season NDVI after the first time period (2000-2004), which may have even greater negative effects on flora and fauna as this is already the most difficult part of the year for them to survive. In Figure 5a, during the initial period (2000-2004), the data supports that the landscape was greener than the long-term mean during the dry season. During the second period (2005-2008), which was a time of less precipitation, the data shows that it was much less green during the dry season than the long-term mean. During the third time period (2009-2012), NDVI was greener than the long-term mean during the wet season. In the fourth time period (2013-2016), it was less green in the first half of the wet season, and greener during the second half of the wet season than the long-term mean. Figure $5 b$ highlights the magnitude of the positive and negative anomalies (seen in Figure $5 a$ ) in both absolute number and percentage. 

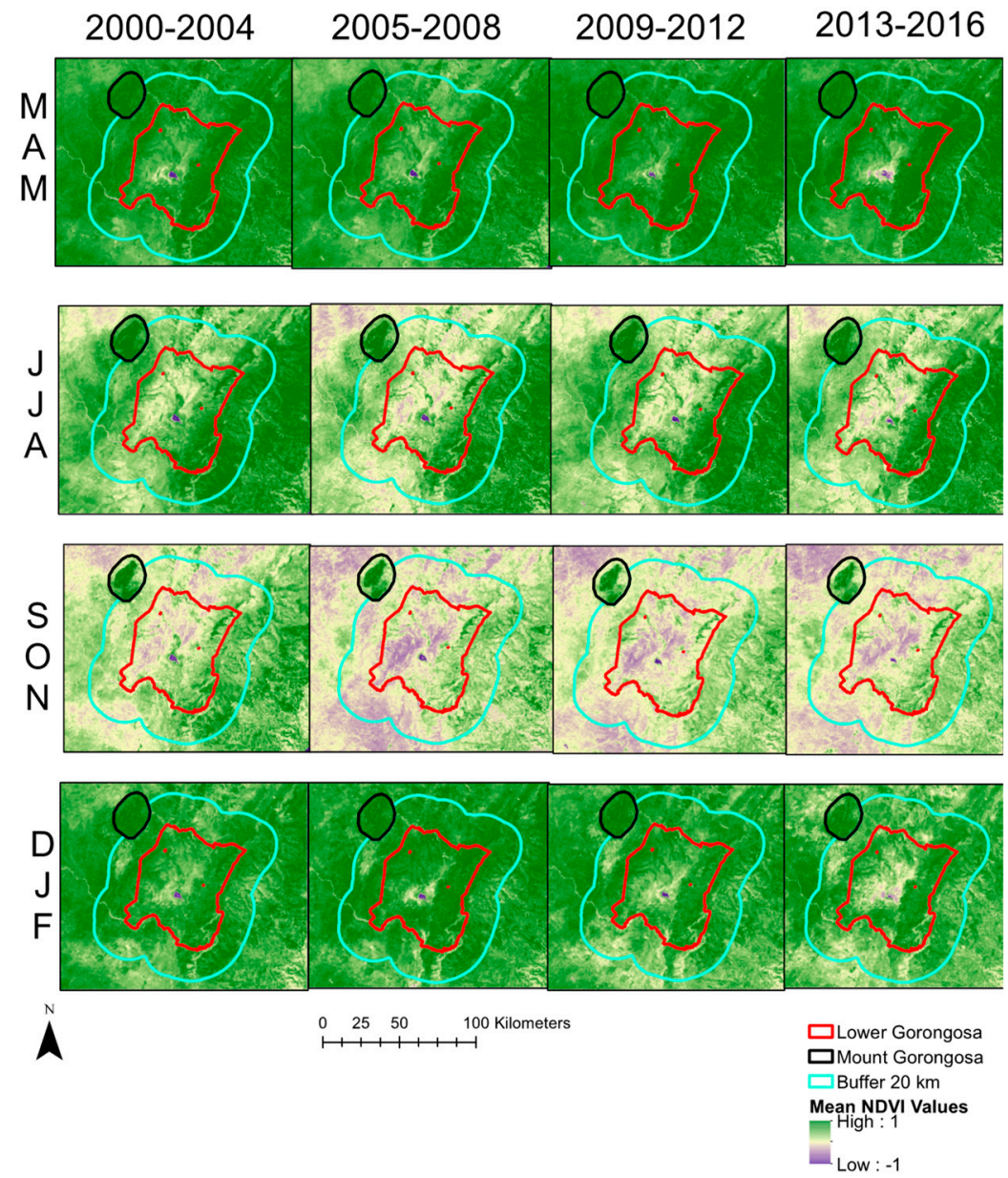

Figure 4. Mean NDVI in Lower Gorongosa and Mount Gorongosa by season: March, April, May (MAM), June, July, August (JJA), September, October, November (SON), December, January, February (DJF) and time periods: 2000-2004, 2005-2008, 2009-2012, 2013-2016.

In order to identify any shifts in the timing of the highest and lowest values of NDVI, the dates during which the seasonally averaged NDVI exceeds (or falls below) the value of the upper (or lower) $10 \%$ of long-term NDVI values are recorded (Figure $5 \mathrm{c}$ ) as an objective indicator of green-up and brown-down. Both the upper and lower limits have moved later in the season, indicating that shifts in climate (precipitation coming later) are already noticeable across this region. Several differences emerge in comparison to long-term characteristics: (a) high levels of greening are attained earlier in the first and second periods (by as much as 30 days), and later in the fourth period (by about 10 days); (b) high levels of NDVI persist until the end of May, except in the second period when declines are noted about half a month earlier; (c) the timing of the lowest values of NDVI show considerably less inter-period variability than those of high levels; (d) the lowest values of NDVI are generally experienced in mid-September, starting slightly earlier in the first and second periods; and (e) the landscape starts to return NDVI values higher at the end of October in all periods. Post management (2009-2016) there seems to have been less variability in these dates (Figure 5c). Shifts in season length are important for future vegetation response and health, with related implications on wildlife and people on this landscape. Specifically, they can have very real consequences for people's livelihood and wildlife health. 

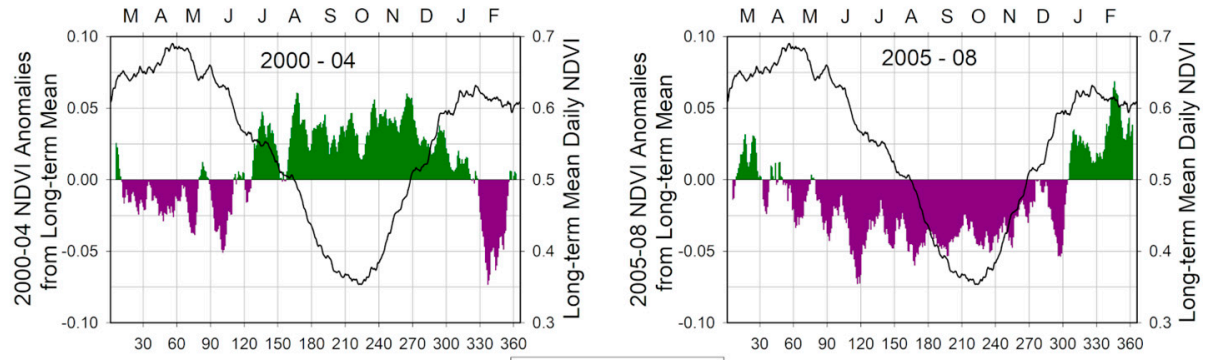

Days since March 1

Negative Anomalies

Days since March 1

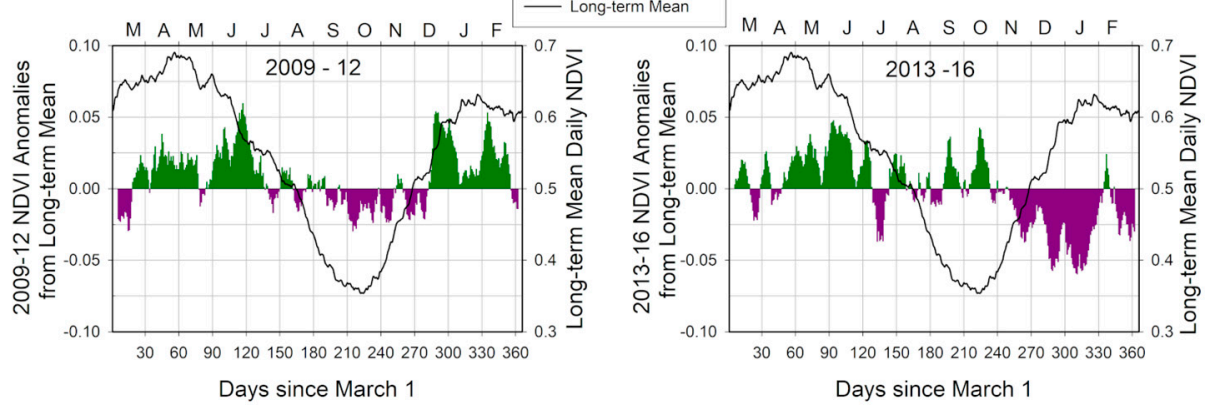

(a)
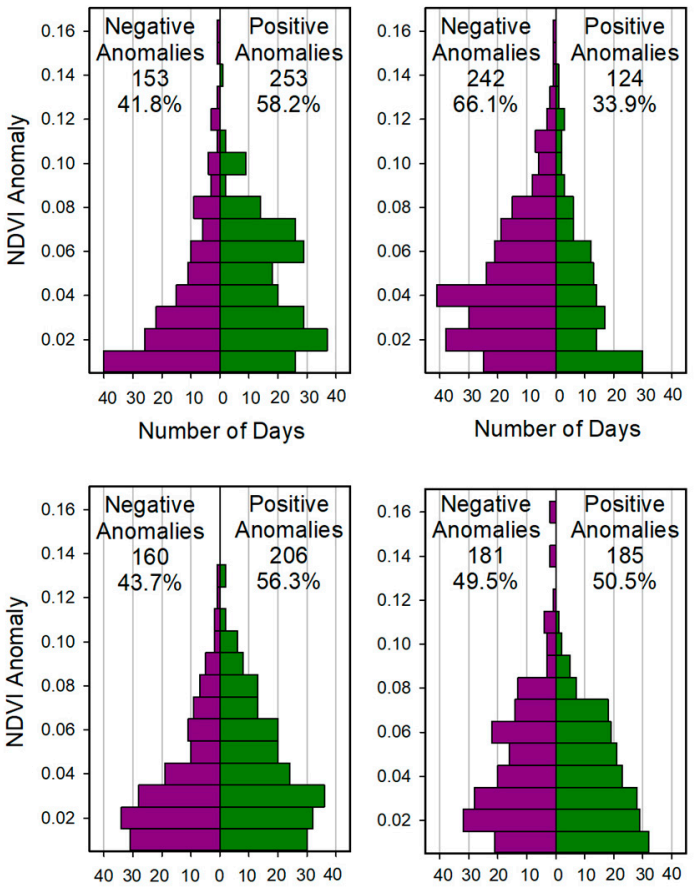

Number of Days

Number of Days

(b)

Figure 5. Cont. 


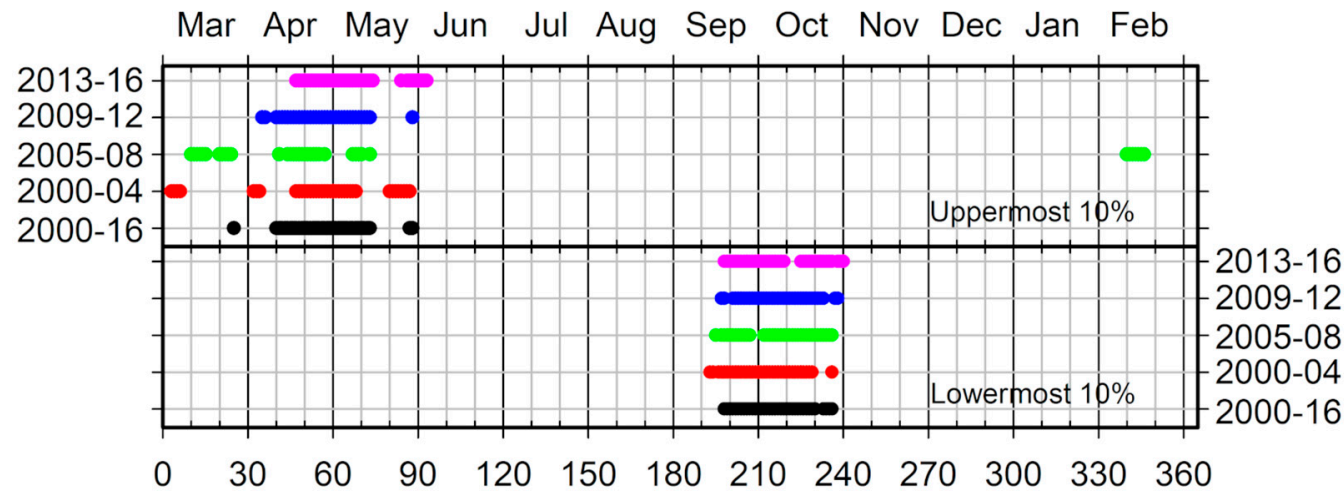

Days Since March 1.

(c)

Figure 5. Daily NDVI (2000-04, 2005-08, 2009-12, 2013-16) of Lower Gorongosa (a) positive and negative anomalies compared to the long term mean (b). NDVI anomalies displaying the frequency of anomaly both as an absolute count and as a percentage of days exhibiting negative and positive anomalies from the long term mean in each of the four periods (left to right and top to bottom 2000-2004, 2005-2008, 2009-2012, 2013-2016), and histograms of the distribution of the magnitudes of those anomalies. (c) The dates on which the uppermost (0.732) and lowermost (0.343) 10\% of NDVI values occurred during the entire period of study and period of interest. The day count on the $x$-axis starts on 1 March, given our seasons for the year start with March-April-May, then June-July-August, then September-October-November, then December into January-February of the following year.

Time series of mean NDVI across the six study areas highlight several important findings. All data reveal decreasing trends, though not all are statistically significant (Figure 6). There are also some similarities between the LG and the $20 \mathrm{~km}$ buffer zone. However, the rate of decline within the buffer zone is steeper than that of LG, suggesting that the conservation and management practices within the park have been effective in mitigating some potential decline [34].

The overall higher NDVI exhibited by MG than LG is attributable to the differing land cover. LG contains varying types of drier savanna, and MG supports montane rainforest. There is a more pronounced and significant decline in NDVI on MG (Figure 6a). This may be due in part to the rainforest of MG supporting higher NDVI and the impacts of human-driven processes such as deforestation being particularly pronounced. Given the land cover types, there is also much less interannual variability in MG when compared to LG. Regardless, the same trends of declining NDVI and precipitation are seen across this landscape.

NDVI was also graphed by land cover type within LG and MG. All land cover types were clearly separable by mean NDVI values. The lowest NDVI values occur in the open savanna vegetation class (0.36-0.69). These increase to $0.41-0.76$ in mixed savanna and $0.51-0.81$ in closed savanna. The highest NDVI occurs in the heavily forested landscape on MG (0.62-0.82) even though there is a significant decline over time (Figure 6a). Given that these three savanna land cover classes within LG are respectively dominated by grassland, shrubland, and woodland, this separation of vegetation abundance (NDVI) makes sense biologically. There is a significant decline in the NDVI of open grassland savanna in LG (Figure 6b) and greater interannual variability than in closed woodland because grasslands are more dependent, in the short term, on precipitation than woodlands are. The smallest and non-significant decline is found in the closed savanna land cover class in LG (Figure 6c) as woody plants tend to be hardier/less vulnerable, which is also supported by the literature $[5,8,20,41]$. 


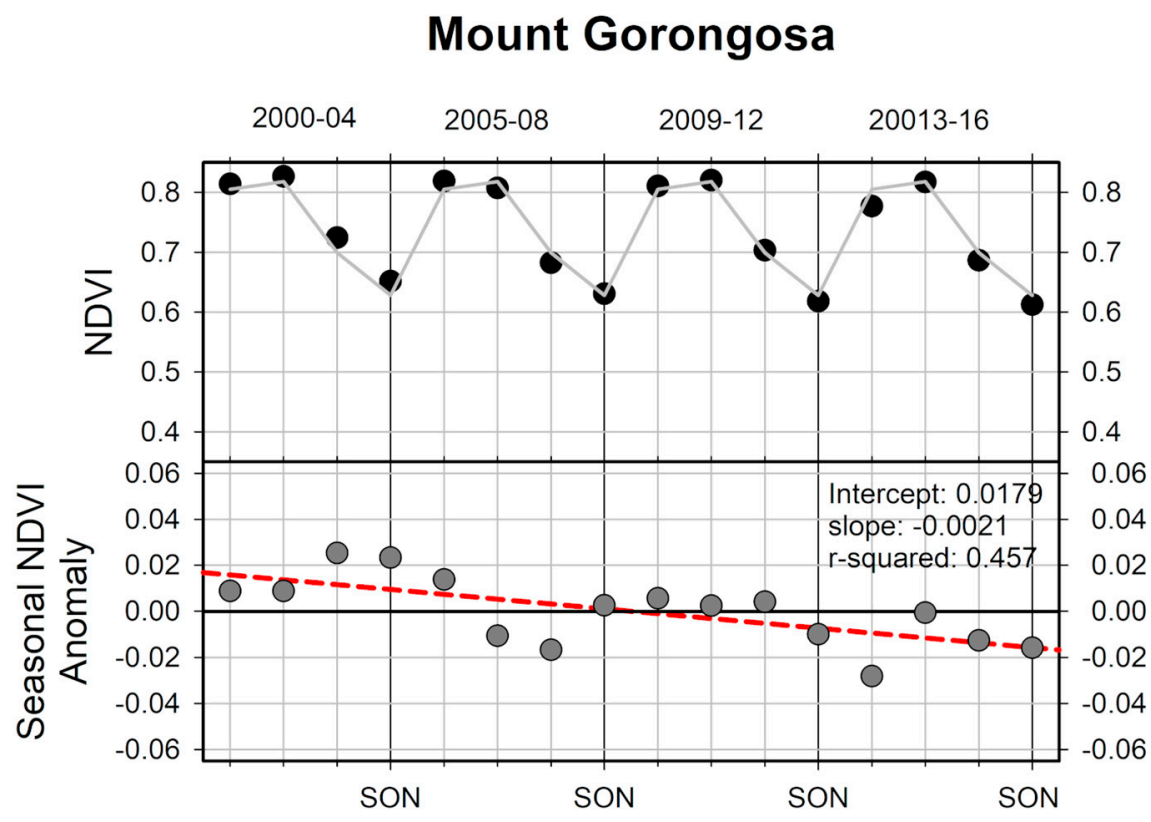

(a)

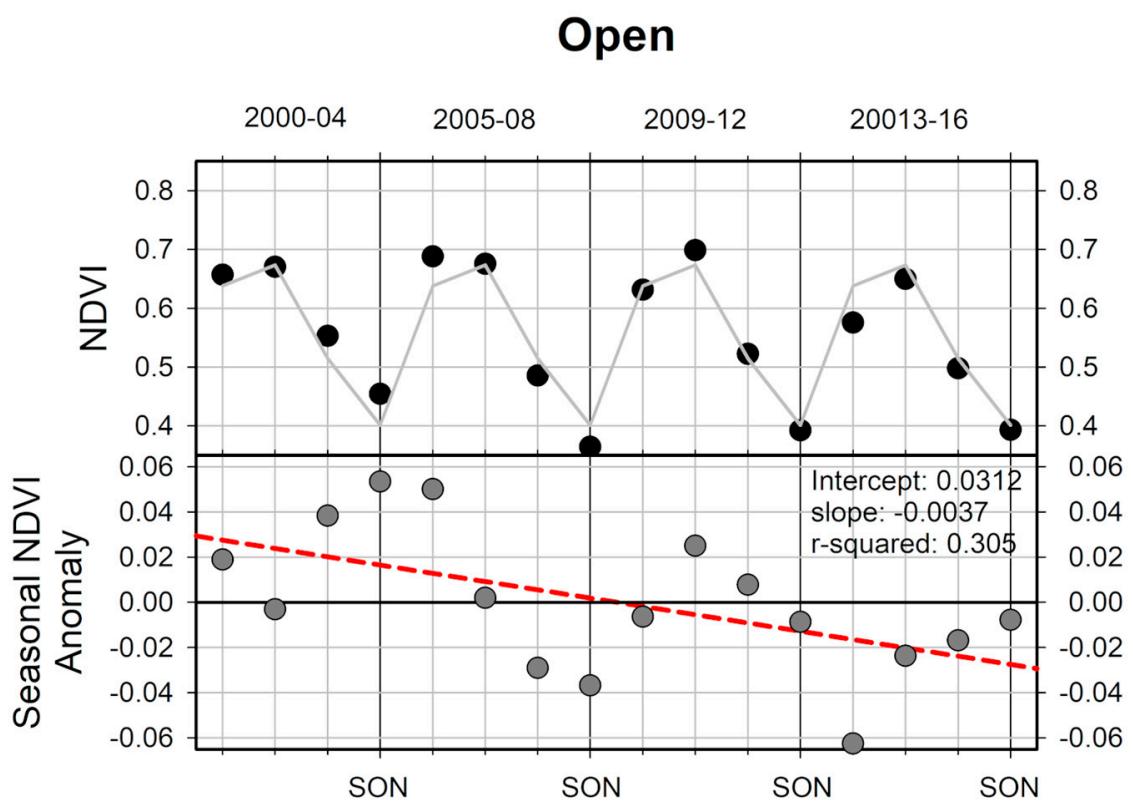

(b)

Figure 6. Cont. 


\section{CLOSED}

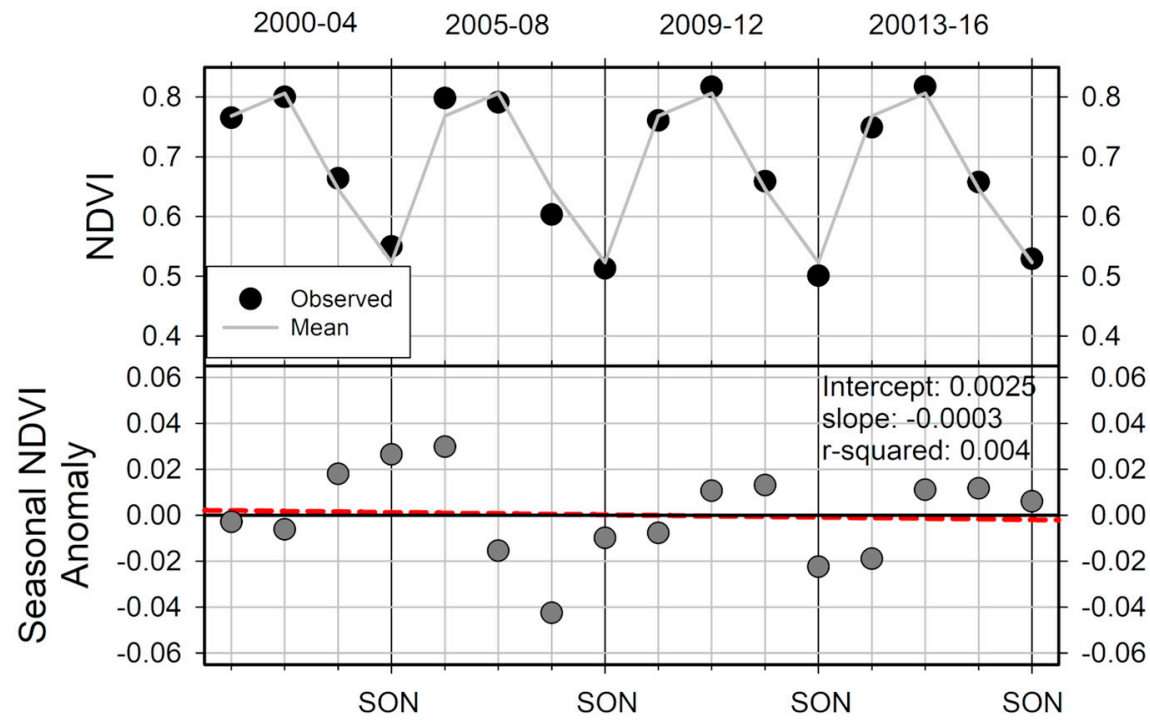

(c)

Figure 6. Time series of mean NDVI seasonally (December-January-February (DJF); March-April-May (MAM); June-July-August (JJA); September-October-November (SON)) from 2000-2016 for (a) Mount Gorongosa (significant trend), (b) open savanna (significant trend), (c) and closed savanna (no significant trend) other non-significant trends (in mixed savanna, LG, and the buffer) are not shown.

In Figure 7a, seasonal precipitation and lagged NDVI are shown. Dry season NDVI is much more sensitive (steeper slope) to small increments in precipitation than the rainy season NDVI. In Figure 7b, there is a significant relationship between precipitation and vegetation in terms of interannual variability (e.g., if there was a wetter than normal wet season versus an unusually high NDVI). This relationship was significant across all seasons of comparison (precipitation to NDVI respectively): FMA to MAM ( $\mathrm{r}$-squared $=0.466$, slope $=0.000416$, and is significant at the 0.01 level); $\mathrm{MJJ}$ to JJA (r-squared $=0.146$, slope $=0.002981$, and is significant at the 0.10 level); ASO to SON ( $r$-squared $=0.570$, slope $=0.005185$, and is significant at the 0.01 level); and NDJ to DJF ( $\mathrm{r}$-squared $=0.247$, slope $=0.000441$, and is significant at the 0.05 level), thus supporting the notion of savanna as a water limited system and precipitation as the main driver of vegetation growth [5]. 


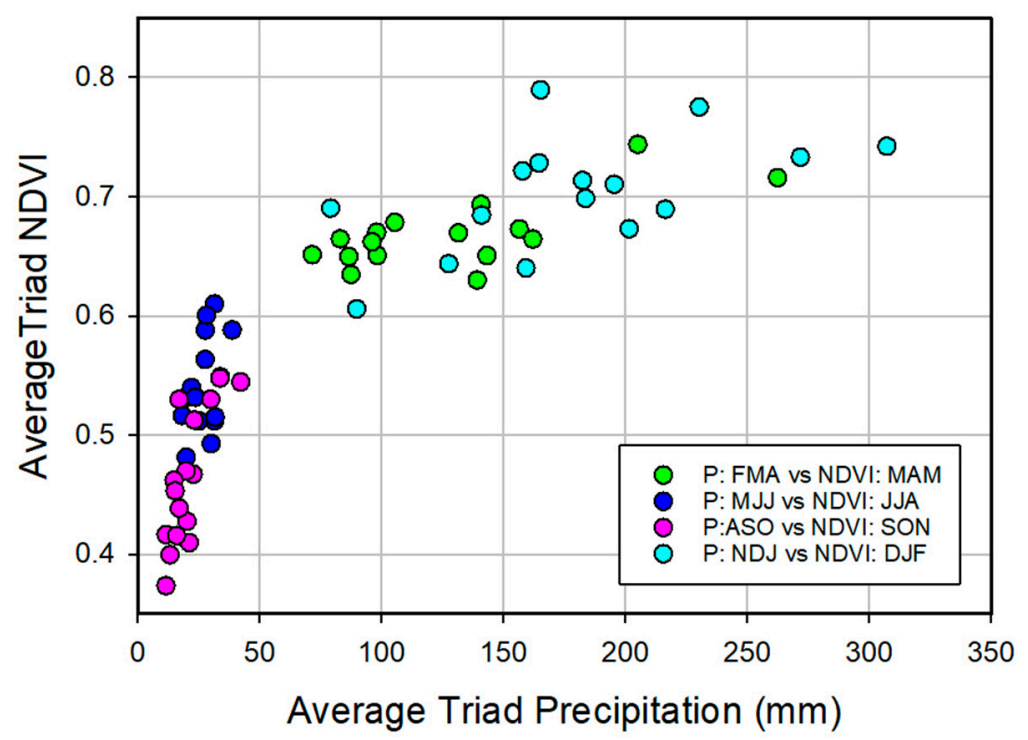

(a)
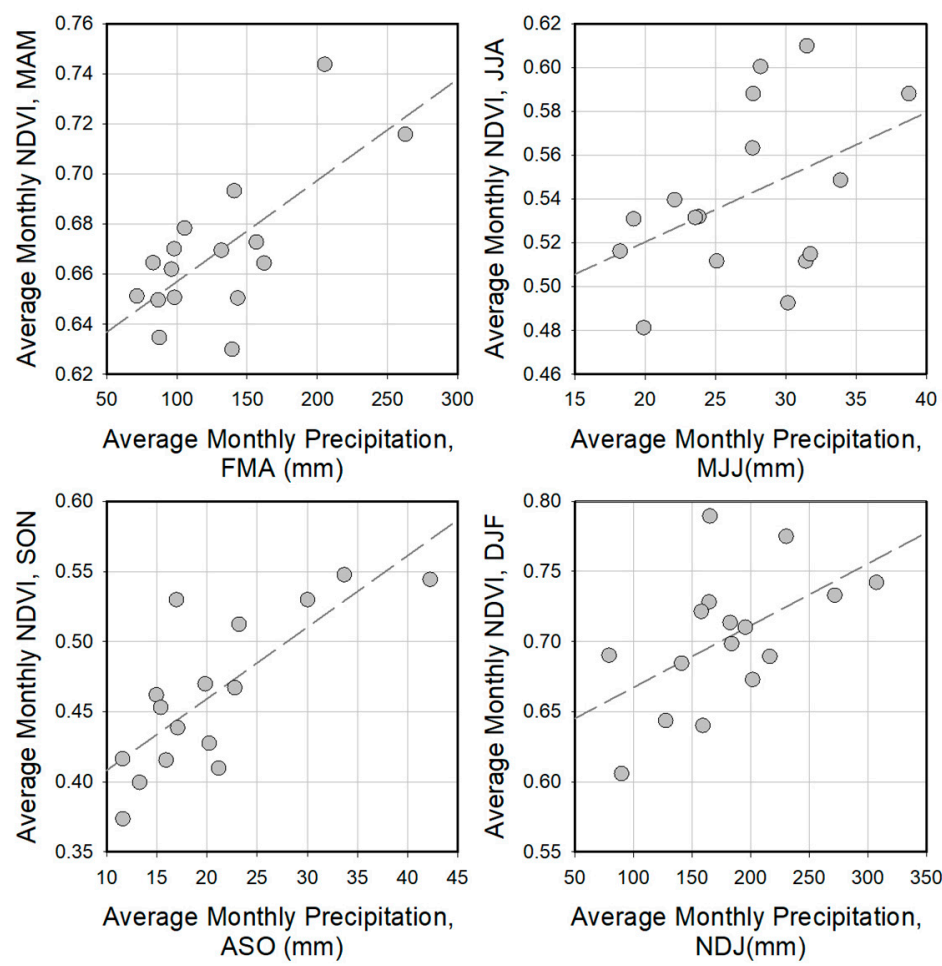

(b)

Figure 7. Precipitation and lagged NDVI (respectively) (a) plotted by season together with different colors for: February, March, April (FMA) to March, April, May (MAM); May, June, July (MJJ) to June, July, August (JJA); August, September, October (ASO) to September, October, November (SON); and November, December, January (NDJ) to December, January, February (DJF) (b) by season individually with fitted regression lines.

\subsection{Tendencies in Vegetation Directional Persistence}

Maps of DP for these study areas (Figure 8) show declines in vegetation, particularly during the dry season and in central LG (which is the open savanna cover, Figure 1) relative to the initial 
baseline period. This area corresponds with open savanna (grassland/floodplain) land cover. There is a dominating negative trend in vegetation persistence during the dry season, particularly in the central part of LG and on MG. During the wet season fewer significant values (positive or negative) of DP prevail. Again similar tendencies are found both inside LG and in the buffer area, though the buffer area has greater negative values of DP.

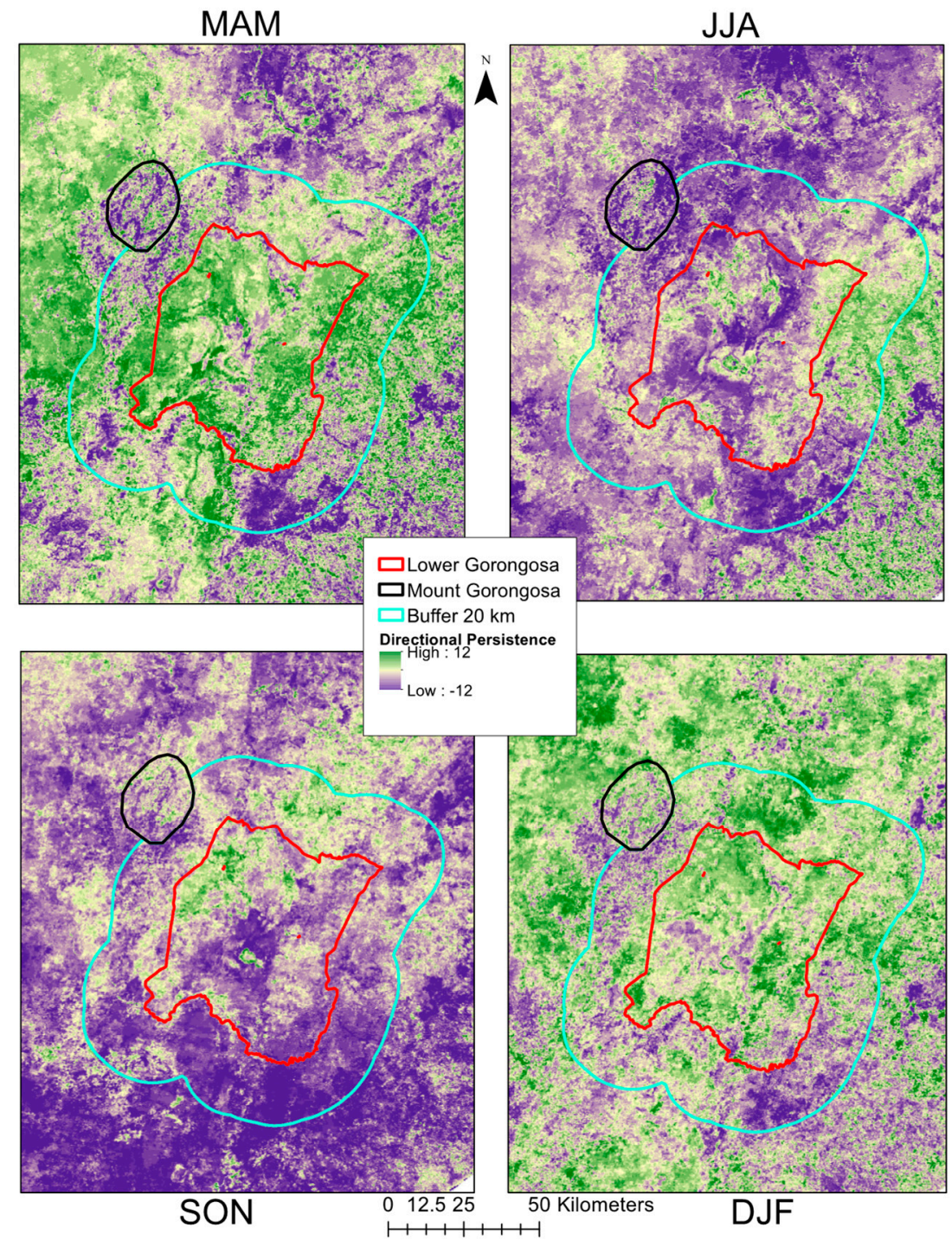

Figure 8. Directional persistence (2005-2016 compared to initial baseline period 2000-2004 at a pixel level) in Lower Gorongosa (including the three savanna types, open, mixed, and closed), Mount Gorongosa, and the buffer zone highlighted by season (MAM = March, April, May, JJA = June, July, August, $\mathrm{SON}=$ September, October, November, DJF = December, January, February).

The seasonal properties of mean directional persistence of all six study areas are presented in Figure 9. Across all study areas, the absolute value of mean persistence is larger during the dry season (more negatively deviated from zero), than the wet season (less positively deviated from zero). This suggests the tendency for NDVI in the dry season to be more negative through time than the baseline value to a greater magnitude than in the wet season. When comparing LG, the buffer zone, and MG, LG had the most positive/least negative mean DP values across seasons. This indicates that, of the six study areas, LG had higher percentages of positive vegetation persistence over time. MG with negative mean DP values across all seasons, shows the most marked decline in vegetation persistence over time. Within the three land cover types in LG, closed savanna had the most positive/least negative 
mean DP values, whereas open savanna had the most negative DP values (Figure 9). OS appears to suffer most in terms of vegetation declines, as found elsewhere in the literature.

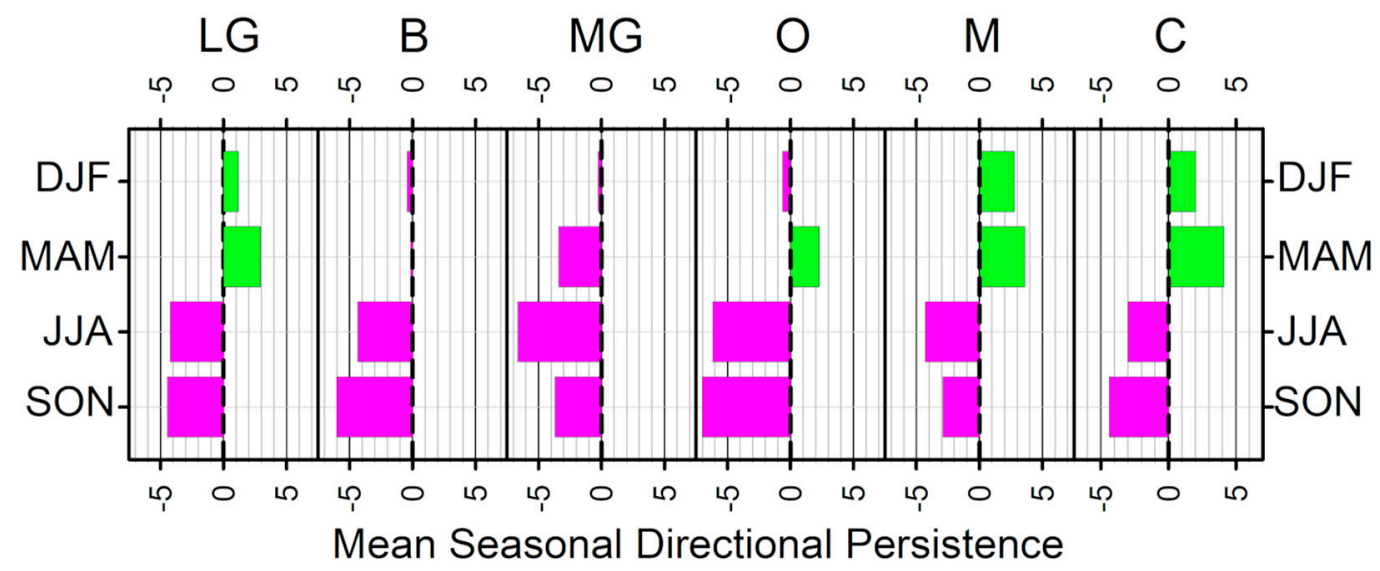

Figure 9. Mean directional persistence values for Lower Gorongosa (LG), the buffer zone (B), Mount Gorongosa (MG), and the three Lower Gorongosa land cover types: open savanna (O), mixed savanna (M), and closed savanna (C) by season (December-January-February (DJF); March-April-May (MAM); June-July-August (JJA); September-October-November (SON)).

Percentage significant positive and negative DP $(+/-6)$ is also calculated for each study area (Figure 10). LG has higher percentages of significant positive DP and lower percentages of significant negative DP than the buffer zone. MG returns higher percentages of significant negative DP and lower percentages of significant positive DP than any other study area. In the dry season, as much as $70 \%$ of the MG landscape has a significant negative DP value. Of the three LG land cover types, open savanna exhibits the highest percentages of significant negative DP. In the dry season, as much as $75 \%$ of the OS landscape has a significant negative DP value. OS also has the lowest percentages of significant positive DP across all seasons. 

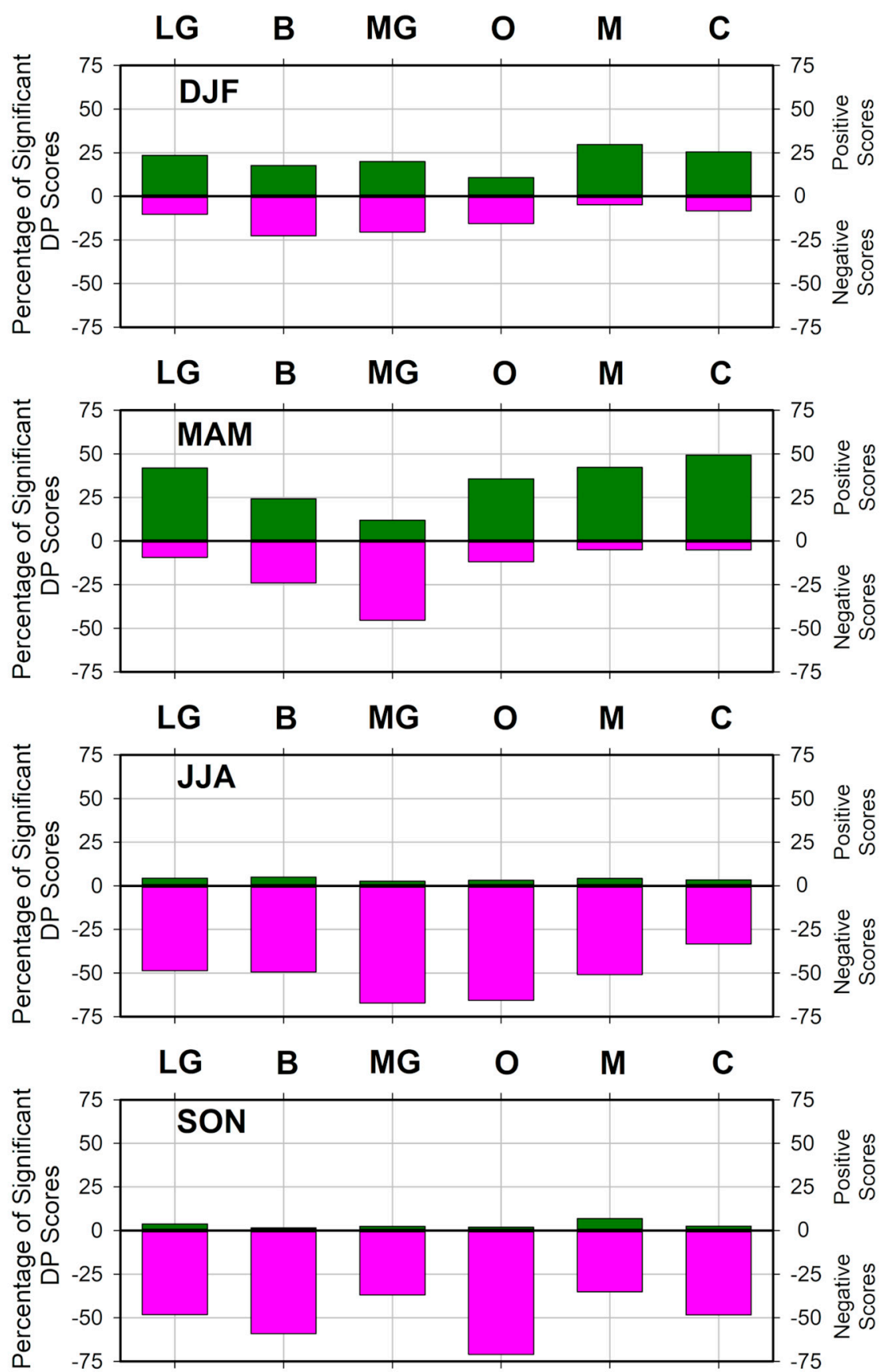

Figure 10. Percentages of significant directional persistence (positive and negative) across the landscapes for: Lower Gorongosa (LG), the buffer zone (B), Mount Gorongosa (MG), and the three Lower Gorongosa land cover types: open savanna (O), mixed savanna (M), and closed savanna (C) by season (December-January-February (DJF); March-April-May (MAM); June-July-August (JJA); September-October-November (SON)).

\section{Discussion}

This study evaluates the relationship between savanna vegetation and precipitation, the role of protected areas in vegetation conservation, and the importance of distinguishing vegetation type for evaluation of its health/persistence. We found that there was a decline in precipitation in Gorongosa National Park over the 2000 to 2016 period, which could be linked to a decline in NDVI. However, we found that there were differences in decline of NDVI amongst savanna land cover classes within LG, with OS having the steepest decline. Compared to the buffer zone, inside the protected area of 
LG had less vegetation decline. MG had the greatest decline of all six study areas in terms of NDVI, as well as the highest negative DP. This may be due to more localized drivers outlined below, but with further conservation efforts, we hope to see more positive trends in the future.

Degradation has been of concern for several decades in savannas [42,43]. Degradation can include several phenomena, including a decrease in biomass of vegetation (seen in this study in and around GNP) and bush encroachment. Bush encroachment is a type of degradation that results in an increase in lower quality short woody plants [12,44,45]. Important drivers of savanna vegetation and therefore potential degradation include, decline in precipitation (already seen here), changes in herbivory (increases to a certain population level may mitigate degradation, but beyond that level, may actually exacerbate it), decreased fire frequency, and humans [4-7,42-47]. Under continued climate change and rewilding, these systems will need to be carefully monitored for further degradation $[15,48]$. One type of bush encroachment reported in the park, particularly in the vulnerable floodplain grasslands, is that of Mimosa pigra. This is due to the previous absence of herbivory (almost no herbivores survived the civil war, allowing encroachers to increase). Now with the heavy reintroduction of herbivores, the park is seeing a decrease in these woody encroachers [84]. However, given the relatively recent rewilding, our longer-term study is seeing the trend of degradation in OS. Though a constant fire regime (the fire regime remains consistent pre- and post-war) has enabled large trees to be able to survive and thrive here $[29,32,33]$. A common way to mitigate the effects of some drivers on the savanna protected area landscape is to implement buffer zones. Buffer zones are areas surrounding parks that act as a more neutral space for activity than the broader landscape. In buffer zones there may be some human activity, but generally it is limited [49]. Creation of these areas increases the distance between protected zones and potential disturbances, limits edge effects, and thereby increases the conservation value of the protected area $[50,51]$.

Jung et al. (2010) [11] point to a global decline in precipitation leading to reduced soil moisture and evapotranspiration. This study found some decrease in precipitation in this region of southeastern Africa during the 21st century [10,44], linked to a decline in vegetation health [10-12], [52,53]. The observed decline in vegetation health (using NDVI as a proxy) further strengthens the link between vegetation biomass in savannas and its main driver, precipitation [5,7-9,12,20-26]. Declines in precipitation and vegetation health suggest that management has not yet had a significant impact on vegetation $[10,53]$ and is still subordinate to the effects of precipitation.

Global greening has been detected over recent decades by remote sensing [53-60]. The most important factors influencing greening appears to be an increase in carbon dioxide and nitrogen levels, land use, temperature, and weather [52,61-63]. Some limited studies have found an opposite trend, specifically that of forest browning $[53,64]$. This research matches more with the browning literature, with decreases in vegetation amount over time. Negative directional persistence in the forests of MG is consistent with literature on browning hotspots globally, especially in subequatorial Africa [10]. de Jong et al., (2013) stress the importance of the scale of the study, and, at a localized scale, direct human interventions, such as deforestation in this landscape, may have more effect than climate. Since rainforests are less climatically driven than savannas [9,54], the significant decline in NDVI on MG may reflect its recent incorporation into the national park and on-going struggles with deforestation for conversion to agriculture and timber harvesting [29]. Therefore, this study provides a local exception to the literature on global greening [53-60]. de Jong et al., (2013) report much less greening in more open savanna cover types, and Southworth et al., (2015) [20] note significant negative trends in dryland vegetation of Mozambique from 1982 to 2010.

These results also highlight the importance of understanding specific vegetation types that make up the heterogeneous savannas [44], whose impacts may otherwise have been masked by contrasting trends. The various rates of decline of NDVI across differing vegetation types underline the importance of understanding the vegetation structural groups within LG and MG [31,65-68]. While all vegetation types examined exhibit declining NDVI, particularly in the dry season, the decline is not equal. In LG, open grassland shows the greatest and most significant decline, whereas the declines of woody 
vegetation cover types (mixed savanna and closed savanna) are not statistically significant. This finding further supports the proposal that open grasslands are the most vulnerable type of savanna because of their strong water-dependence and vulnerability to encroachment $[5,8,10,20,41]$.

A principal purpose of protected areas is to conserve vegetation. Placement of the park on the landscape and proximity to humans can be as important in achieving this goal as biophysical variables, such as climate and soil [34,69-73]. The NDVI time series and directional persistence demonstrate that despite evidence of a strong link between precipitation and vegetation [11], protected areas can be effective in conserving vegetation. Vegetation inside protected areas tends to fare better than in surrounding areas [34]. Management practices of the LG protected area seem to be conserving vegetation better than in the buffer zones, as suggested by the smaller declines in NDVI compared to the surrounding buffer areas. MG is unique in the sense that management practices are not yet fully implemented and some deforestation persists, with concomitant detrimental impacts on NDVI as reported globally $[20,24,25,74-84]$.

More locally, this study will help the park management team identify areas for conservation and those most vulnerable to vegetation decline like the grasslands and MG, both of which are key to tourism - the socioeconomic driver of this region. While precipitation data correspond very well with NDVI, a limitation of this study is that the data are resolved at a coarse spatial scale $\left(0.05^{\circ}\right)$ relative to the study area [36], and that gridded datasets are dependent on the availability of local observations and satellite data, which may not be robust in this system. Another important note concerning DP values is that this is an NDVI comparison to the baseline in number of years above or below the baseline, but this measure does not account for magnitude of difference.

In the context of the broader landscape, this park seems to be maintaining vegetation health, and proving its effectiveness as a protected area in this respect. There were similar, but more negative trends detected in the buffer zone. Going forward, the park management team's work with community projects should also have a positive effect in the buffer zone. Though, socioeconomically speaking, this new model of conservation is already mutually beneficial for conservation [29]. One effort to combat deforestation on MG and stimulate the local economy is the production of shade-grown coffee [29]. This year, the shade-grown coffee being grown on MG is being sold globally. The park is currently expanding this coffee by 100 hectares per year, and by the year 2025, they will have developed 1000 hectares of coffee plantation. This translates to over 5000 hectares of restored forest cover on and around MG [29].

Significant mammal restocking, both herbivore (i.e., antelope) and carnivore (i.e., painted wolves), is also underway in the park, and more is planned in the future. Given the importance of herbivory as a driver in savanna landscapes and possible bush encroachment, the monitoring and measurement of vegetation cover change in this region is essential. The park can serve as an interesting comparison study to many other parks in southern Africa that are already suffering from bush encroachment and degradation due to overstocking [42-46]. The role of GNP, both as a crucial conservation area in this landscape, and as an important area for monitoring and research given its unique historical trajectory, cannot be overstated. Future monitoring and research will be of key importance to the management of African parks.

\section{Conclusions}

This study finds a declining trend in precipitation in GNP from 2000-2016, though the pre(2000-2008) and post- (2009-2016) management precipitation regimes are not found to be statistically different. There is a corresponding decrease in NDVI over time across the entire study area. Different vegetation types display varying rates of decline in NDVI with grasslands and rainforest exhibiting the steepest (and significant) decline. Woody savanna vegetation experienced the least decline in NDVI over time.

The directional persistence metric evidences significant declines in vegetation biomass 2005-2016 compared to the 2000-2004 baseline. Negative persistence is strongest on MG, possibly reflecting 
continuing deforestation issues and the area's recent incorporation under protection. Open grassland savanna in LG also experienced significant negative persistence. LG experiences smaller declines in vegetation biomass and smaller values of directional persistence compared to the buffer zone, suggesting that the park is functioning effectively in conserving vegetation. Overall, there have been declines in vegetation in and around GNP during the 21st century. These declines may be prompted by a decline in precipitation, a shift in the seasonal timing of this precipitation, and direct human action. However, LG fares better than the surrounding area, further strengthening the justification for protected areas. The "laboratory" provided by this particular park and its unique history will be useful not only to scientists, but also to managers of protected areas, particularly savannas, as they can separate out the differing impacts of natural changes (such as precipitation which are outside manager control) and manmade changes (such as linked to deforestation, management rules etc.).

Author Contributions: Conceptualization, H.H., J.S., and B.C.; methodology, J.S. and P.W.; software, R.K.; formal analysis, H.H., R.K., P.W., and D.Y.; data curation, R.K., H.H., and D.Y.; writing-original draft preparation, H.H. and J.S.; writing-review and editing, J.S., P.W., R.K., H.H., D.Y. and B.C. All authors have read and agreed to the published version of the manuscript.

Funding: This research received no external funding.

Acknowledgments: These authors would like to thank the Gorongosa National Park Management/Science Team for their input on vegetation covers in the park and background information.

Conflicts of Interest: The authors declare no conflict of interest.

\section{References}

1. Chapin, F.S., III; Matson, P.A.; Vitousek, P. Principles of Terrestrial Ecosystem Ecology; Springer: New York, NY, USA, 2011.

2. Hanan, N.; Lehmann, C. Tree-Grass Interactions in Savannas: Paradigms, Contradictions, and Conceptual Models. Available online: https://www.taylorfrancis.com/books/e/9780429132469/chapters/10.1201\% 2Fb10275-10 (accessed on 23 September 2019).

3. Scholes, R.J.; Walker, B.H. An. African savanna: Synthesis of the Nylsvley Study; Cambridge University Press: Cambridge, UK, 1993.

4. Andela, N.; Liu, Y.Y.; Van Dijk, A.I.J.M.; De Jeu, R.A.M.; McVicar, T.R. Global changes in dryland vegetation dynamics (1988-2008) assessed by satellite remote sensing: Comparing a new passive microwave vegetation density record with reflective greenness data. Biogeosciences 2013, 10, 6657-6676. [CrossRef]

5. Campo-Bescos, M.A.; Munoz-Carpena, R.; Kaplan, D.A.; Southworth, J.; Zhu, L.; Waylen, P.R. Beyond Precipitation: Physiographic Gradients Dictate the Relative Importance of Environmental Drivers on Savanna Vegetation. PLoS ONE 2013, 8, e72348. [CrossRef]

6. Lehmann, C.E.; Anderson, T.M.; Sankaran, M.; Higgins, S.I.; Archibald, S.; Hoffmann, W.A.; Hanan, N.P.; Williams, R.J.; Fensham, R.J.; Felfili, J.; et al. Savanna Vegetation-Fire-Climate Relationships Differ Among Continents. Science 2014, 343, 548-552. [CrossRef] [PubMed]

7. Sankaran, M.; Hanan, N.P.; Scholes, R.J.; Ratnam, J.; Augustine, D.J.; Cade, B.S.; Gignoux, J.; Higgins, S.I.; Le Roux, X.; Ludwig, F.; et al. Determinants of woody cover in African savannas. Nature 2005, 438, 846-849. [CrossRef] [PubMed]

8. Scholes, R.J.; Archer, S.R. Tree-Grass Interactions in Savannas. Annu. Rev. Ecol. Syst. 1997, $28,517-544$. [CrossRef]

9. Staver, A.C.; Archibald, S.; Levin, S. Tree cover in sub-Saharan Africa: Rainfall and fire constrain forest and savanna as alternative stable states. Ecology 2011, 92, 1063-1072. [CrossRef]

10. De Jong, R.; Verbesselt, J.; Zeileis, A.; Schaepman, M.E. Shifts in Global Vegetation Activity Trends. Remote Sens. 2013, 5, 1117-1133. [CrossRef]

11. Jung, M.; Reichstein, M.; Ciais, P.; Seneviratne, S.I.; Sheffield, J.; Goulden, M.L.; Bonan, G.; Cescatti, A.; Chen, J.; De Jeu, R.; et al. Recent decline in the global land evapotranspiration trend due to limited moisture supply. Nature 2010, 467, 951-954. [CrossRef] 
12. Bunting, E.L.; Fullman, T.; Kiker, G.; Southworth, J. Utilization of the SAVANNA model to analyze future patterns of vegetation cover in Kruger National Park under changing climate. Ecol. Model. 2016, 342, 147-160. [CrossRef]

13. Houghton, E. Climate Change 1995: The Science of Climate Change: Contribution of Working Group I to the Second Assessment Report of the Intergovernmental Panel on Climate Change; Cambridge University Press: Cambridge, UK, 1996.

14. Houghton, R.A.; Hackler, J.L.; Lawrence, K.T. The U.S. Carbon Budget: Contributions from Land-Use Change. Science 1999, 285, 574-578. [CrossRef]

15. Monserud, R.A.; Tchebakova, N.M.; Leemans, R. Global vegetation change predicted by the modified Budyko model. Clim. Chang. 1993, 25, 59-83. [CrossRef]

16. Ojima, D.S.; Valentine, D.W.; Mosier, A.R.; Parton, W.J.; Schimel, D.S. Effect of land use change on methane oxidation in temperate forest and grassland soils. Chemosphere 1993, 26, 675-685. [CrossRef]

17. Scholes, R.J.; Hall, D.O. The carbon budget of tropical savannas, woodlands, and grasslands. SCOPE-Sci. Comm. Probl. Environ. Int. Counc. Sci. Unions 1996, 56, 69-100.

18. Child, B. Zimbabwe's CAMPFIRE programme: Using the high value of wildlife recreation to revolutionize natural resource management in communal areas. Commonw. For. Rev. 1993, 72, 284-296.

19. Waylen, P.; Southworth, J.; Gibbes, C.; Tsai, H. Time Series Analysis of Land Cover Change: Developing Statistical Tools to Determine Significance of Land Cover Changes in Persistence Analyses. Remote Sens. 2014, 6, 4473-4497. [CrossRef]

20. Southworth, J.; Zhu, L.; Bunting, E.; Ryan, S.J.; Herrero, H.; Waylen, P.R.; Hill, M.J. Changes in vegetation persistence across global savanna landscapes, 1982-2010. J. Land Use Sci. 2016, 11, 7-32. [CrossRef]

21. Carlson, T.N.; Ripley, D.A. On the relation between NDVI, fractional vegetation cover, and leaf area index. Remote Sens. Environ. 1997, 62, 241-252. [CrossRef]

22. Bégué, A.; Vintrou, E.; Ruelland, D.; Claden, M.; Dessay, N. Can a 25-year trend in Soudano-Sahelian vegetation dynamics be interpreted in terms of land use change? A remote sensing approach. Glob. Environ. Chang. 2011, 21, 413-420. [CrossRef]

23. Jiang, Z.; Huete, A.R.; Chen, J.; Chen, Y.; Li, J.; Yan, G.; Zhang, X. Analysis of NDVI and scaled difference vegetation index retrievals of vegetation fraction. Remote Sens. Environ. 2006, 101, 366-378. [CrossRef]

24. Lambin, E.F.; Ehrlich, D. Land-cover changes in sub-saharan Africa (1982-1991): Application of a change index based on remotely sensed surface temperature and vegetation indices at a continental scale. Remote Sens. Environ. 1997, 61, 181-200. [CrossRef]

25. Tucker, C.J. Red and photographic infrared linear combinations for monitoring vegetation. Remote Sens. Environ. 1979, 8, 127-150. [CrossRef]

26. Wang, J.; Rich, P.M.; Price, K.P.; Kettle, W.D. Relations between NDVI, Grassland Production, and Crop Yield in the Central Great Plains. Geocarto Int. 2005, 20, 5-11. [CrossRef]

27. Müller, T.; Mapaura, A.; Wursten, B.; Chapano, C.; Ballings, P.; Wild, R. Vegetation Survey of Mount Gorongosa. Available online: http://dev.gorongosa.forumone.com/sites/default/files/research/041-bfa_no.23_ gorongosa_vegetation_survey.pdf (accessed on 30 January 2020).

28. Rahbek, C.; Borregaard, M.K.; Colwell, R.K.; Dalsgaard, B.; Holt, B.G.; Morueta-Holme, N.; Nogues-Bravo, D.; Whittaker, R.J.; Fjeldså, J. Humboldt's enigma: What causes global patterns of mountain biodiversity? Science 2019, 365, 1108-1113. [CrossRef] [PubMed]

29. Gorongosa National Park Website. Available online: www.gorongosa.org (accessed on 30 January 2020).

30. Adams, P. Opinion | A Comeback for African National Parks. Available online: https://www.nytimes.com/ 2019/02/20/opinion/africa-national-parks.html (accessed on 30 January 2020).

31. Tinley, K.L. Framework of the Gorongosa Ecosystem. Available online: https://www.gorongosa.org/ourstory/science/reports/framework-gorongosa-ecosystem (accessed on 30 January 2020).

32. Daskin, J.H.; Stalmans, M.; Pringle, R.M. Ecological legacies of civil war: 35-year increase in savanna tree cover following wholesale large-mammal declines. J. Anim. Ecol. 2016, 104, 79-89. [CrossRef]

33. Herrero, H.V.; Southworth, J.; Bunting, E.; Child, B. Using Repeat Photography to Observe Vegetation Change Over Time in Gorongosa National Park. Available online: https://geog.ufl.edu/2017/06/26/usingrepeat-photography-to-observe-vegetation-change-over-time-in-gorongosa-national-park/ (accessed on 30 January 2020). 
34. DeFries, R.; Hansen, A.; Turner, B.L.; Reid, R.; Liu, J. Land Use Change Around Protected Areas: Management to Balance Human Needs and Ecological Function. Ecol. Appl. 2007, 17, 1031-1038. [CrossRef] [PubMed]

35. Measuring Vegetation (NDVI \& EVI). Available online: https://earthobservatory.nasa.gov/features/ MeasuringVegetation (accessed on 24 September 2019).

36. Funk, C.; Peterson, P.; Landsfeld, M.; Pedreros, D.; Verdin, J.; Shukla, S.; Husak, G.; Rowland, J.; Harrison, L.; Hoell, A.; et al. The climate hazards infrared precipitation with stations-a new environmental record for monitoring extremes. Sci. Data 2015, 2,1-21. [CrossRef] [PubMed]

37. Nicholson, S.E. The nature of rainfall variability over Africa on time scales of decades to millenia. Glob. Planet. Chang. 2000, 26, 137-158. [CrossRef]

38. Dezfuli, A.K.; Zaitchik, B.F.; Gnanadesikan, A. Regional Atmospheric Circulation and Rainfall Variability in South Equatorial Africa. J. Clim. 2014, 28, 809-818. [CrossRef]

39. Zhu, L.; Southworth, J. Disentangling the Relationships between Net Primary Production and Precipitation in Southern Africa Savannas Using Satellite Observations from 1982 to 2010. Remote Sens. 2013, 5, 3803-3825. [CrossRef]

40. 3.2 Hypergeometric Distribution, 3.5, 3.9 Mean and Variance. Available online: http://www.math.ucsd.edu/ $\sim\{$ ggptesler/186/slides/186_hypergeom_17-handout.pdf (accessed on 30 January 2020).

41. Jeltsch, F.; Weber, G.E.; Grimm, V. Ecological buffering mechanisms in savannas: A unifying theory of long-term tree-grass coexistence. Plant. Ecol. 2000, 150, 161-171. [CrossRef]

42. Campbell, A.; Child, G. The Impact of Man on the Environment of Botswana. Botsw. Notes Rec. 1971, 3, 91-110.

43. Child, G. An Ecological Survey of Northeastern Botswana; Food and Agriculture Organization of the United Nations: Rome, Italy, 1968.

44. Herrero, H.V.; Southworth, J.; Bunting, E. Utilizing Multiple Lines of Evidence to Determine Landscape Degradation within Protected Area Landscapes: A Case Study of Chobe National Park, Botswana from 1982 to 2011. Remote Sens. 2016, 8, 623. [CrossRef]

45. Moleele, N.M.; Ringrose, S.; Matheson, W.; Vanderpost, C. More woody plants? the status of bush encroachment in Botswana's grazing areas. J. Environ. Manag. 2002, 64, 3-11. [CrossRef] [PubMed]

46. Ringrose, S.; Matheson, W.; Wolski, P.; Huntsman-Mapila, P. Vegetation cover trends along the Botswana Kalahari transect. J. Arid Environ. 2003, 54, 297-317. [CrossRef]

47. Van Wilgen, B.W.; Govender, N.; Biggs, H.C.; Ntsala, D.; Funda, X.N. Response of Savanna Fire Regimes to Changing Fire-Management Policies in a Large African National Park. Conserv. Biol. 2004, 18, 1533-1540. [CrossRef]

48. Vitousek, P.M.; Mooney, H.A.; Lubchenco, J.; Melillo, J.M. Human Domination of Earth's Ecosystems. Science 1997, 277, 494-499. [CrossRef]

49. Wells, M.; Bradon, K. People and Parks: Linking Protected Area Management with Local Communities; World Bank: Washington, DC, USA, 1992.

50. Sayer, J. Rainforest Buffer Zones: Guidelines for Protected Area Managers; International Union for Conservation of Nature and Natural Resources: Gland, Switzerland, 1991.

51. Martino, D. Buffer Zones Around Protected Areas: A Brief Literature Review. Available online: https: //escholarship.org/content/qt02n4v17n/qt02n4v17n.pdf (accessed on 30 January 2020).

52. De Jong, R.; de Bruin, S.; de Wit, A.; Schaepman, M.E.; Dent, D.L. Analysis of monotonic greening and browning trends from global NDVI time-series. Remote Sens. Environ. 2011, 115, 692-702. [CrossRef]

53. De Jong, R.; Verbesselt, J.; Schaepman, M.E.; De Bruin, S. Trend changes in global greening and browning: Contribution of short-term trends to longer-term change. Glob. Chang. Biol. 2012, 18, 642-655. [CrossRef]

54. Mitchard, E.T.; Saatchi, S.S.; Gerard, F.F.; Lewis, S.L.; Meir, P. Measuring Woody Encroachment along a Forest-Savanna Boundary in Central Africa. Earth Interact. 2009, 13, 1-29. [CrossRef]

55. Piao, S.; Wang, X.; Ciais, P.; Zhu, B.; Wang, T.A.O.; Liu, J.I.E. Changes in satellite-derived vegetation growth trend in temperate and boreal Eurasia from 1982 to 2006. Glob. Chang. Biol. 2011, 17, 3228-3239. [CrossRef]

56. Guay, K.C.; Beck, P.S.; Berner, L.T.; Goetz, S.J.; Baccini, A.; Buermann, W. Vegetation productivity patterns at high northern latitudes: A multi-sensor satellite data assessment. Glob. Chang. Biol. 2014, 20, 3147-3158. [CrossRef] [PubMed] 
57. Brandt, M.; Mbow, C.; Diouf, A.A.; Verger, A.; Samimi, C.; Fensholt, R. Ground- and satellite-based evidence of the biophysical mechanisms behind the greening Sahel. Glob. Chang. Biol. 2015, 21, 1610-1620. [CrossRef] [PubMed]

58. Schimel, D.; Pavlick, R.; Fisher, J.B.; Asner, G.P.; Saatchi, S.; Townsend, P.; Miller, C.; Frankenberg, C.; Hibbard, K.; Cox, P. Observing terrestrial ecosystems and the carbon cycle from space. Glob. Chang. Biol. 2015, 21, 1762-1776. [CrossRef] [PubMed]

59. Garonna, I.; de Jong, R.; Schaepman, M.E. Variability and evolution of global land surface phenology over the past three decades (1982-2012). Glob. Chang. Biol. 2016, 22, 1456-1468. [CrossRef] [PubMed]

60. Bastin, J.F.; Berrahmouni, N.; Grainger, A.; Maniatis, D.; Mollicone, D.; Moore, R.; Patriarca, C.; Picard, N.; Sparrow, B.; Abraham, E.M.; et al. The extent of forest in dryland biomes. Science 2017, 356, 635-638. [CrossRef] [PubMed]

61. Olsson, L.; Eklundh, L.; Ardö, J. A recent greening of the Sahel-trends, patterns and potential causes. J. Arid Environ. 2005, 63, 556-566. [CrossRef]

62. Zhang, K.; Kimball, J.S.; Nemani, R.R.; Running, S.W.; Hong, Y.; Gourley, J.J.; Yu, Z. Vegetation Greening and Climate Change Promote Multidecadal Rises of Global Land Evapotranspiration. Sci. Rep. 2015, 5, 15956. [CrossRef]

63. Zhu, Z.; Piao, S.; Myneni, R.B.; Huang, M.; Zeng, Z.; Canadell, J.G.; Ciais, P.; Sitch, S.; Friedlingstein, P.; Arneth, A.; et al. Greening of the Earth and its drivers. Nat. Clim. Chang. 2016, 6, 791-795. [CrossRef]

64. Alcaraz-Segura, D.O.; Chuvieco, E.; Epstein, H.E.; Kasischke, E.S.; Trishchenko, A. Debating the greening vs. browning of the North American boreal forest: Differences between satellite datasets. Glob. Chang. Biol. 2010, 16, 760-770. [CrossRef]

65. Cunliffe, R.; Lynam, T. Preliminary Vegetation Classification and Mapping of Gorongosa National Park, Sofala Province, Mozambique. Available online: https:/www.gorongosa.org/sites/default/files/research/018cunliffe_lynam_veg._classification_and_mapping_1-05.pdf (accessed on 30 January 2020).

66. Stalmans, M. Tinley's Plant Species List for the Greater Gorongosa Ecosystem. Available online: http://dev.gorongosa.forumone.com/sites/default/files/research/052-stalmans_tinley_plant_species_ list_gorongosa.pdf (accessed on 30 January 2020).

67. Stalmans, M.; Beilfuss, R. Long-Term Plan for Gorongosa National Park Vegetation Monitoring at Multiple Scales. Available online: https:/www.researchgate.net/profile/Richard_Beilfuss/publication/ 313728082_Long-term_plan_for_Gorongosa_National_Park_vegetation_monitoring_at_multiple_scales/ links/58a43c59a6fdcc0e0751a8a0/Long-term-plan-for-Gorongosa-National-Park-vegetation-monitoringat-multiple-scales.pdf (accessed on 30 January 2020).

68. Stalmans, M.; Beilfuss, R. Landscapes of the Gorongosa National Park. Available online: https://www. researchgate.net/publication/314878798_Landscapes_of_the_Gorongosa_National_Park (accessed on 30 January 2020).

69. Barnes, M.D.; Glew, L.; Wyborn, C.; Craigie, I.D. Prevent perverse outcomes from global protected area policy. Nat. Ecol. Evol. 2018, 2, 759-762. [CrossRef]

70. Fuller, R.A.; McDonald-Madden, E.; Wilson, K.A.; Carwardine, J.; Grantham, H.S.; Watson, J.E.; Klein, C.J.; Green, D.C.; Possingham, H.P. Replacing underperforming protected areas achieves better conservation outcomes. Nature 2010, 466, 365-367. [CrossRef]

71. Newmark, W.D. Insularization of Tanzanian Parks and the Local Extinction of Large Mammals. Conserv. Biol. 1996, 10, 1549-1556. [CrossRef]

72. Rodrigues, A.S.; Andelman, S.J.; Bakarr, M.I.; Boitani, L.; Brooks, T.M.; Cowling, R.M.; Fishpool, L.D.; Da Fonseca, G.A.; Gaston, K.J.; Hoffmann, M.; et al. Effectiveness of the global protected area network in representing species diversity. Nature 2004, 428, 640-643. [CrossRef]

73. Saura, S.; Bertzky, B.; Bastin, L.; Battistella, L.; Mandrici, A.; Dubois, G. Protected area connectivity: Shortfalls in global targets and country-level priorities. Biol. Conserv. 2018, 219, 53-67. [CrossRef] [PubMed]

74. De Almeida, A.S.; Stone, T.A.; Vieira, I.C.G.; Davidson, E.A. Nonfrontier Deforestation in the Eastern Amazon. Earth Interact. 2010, 14, 1-15. [CrossRef]

75. Ingram, J.C.; Dawson, T.P. Technical Note: Inter-annual analysis of deforestation hotspots in Madagascar from high temporal resolution satellite observations. Int. J. Remote Sens. 2005, 26, 1447-1461. [CrossRef]

76. Jin, Y.; Sung, S.; Lee, D.K.; Biging, G.S.; Jeong, S. Mapping Deforestation in North Korea Using Phenology-Based Multi-Index and Random Forest. Remote Sens. 2016, 8, 997. [CrossRef] 
77. Kumar, P.; Rani, M.; Pandey, P.C.; Majumdar, A.; Nathawat, M.S. Monitoring of Deforestation and Forest Degradation Using Remote Sensing and GIS: A Case Study of Ranchi in Jharkhand (India). Available online: https://s3.amazonaws.com/academia.edu.documents/27495816/03_2578_ report0204_14_20.pdf?response-content-disposition=inline\%3B\%20filename\%3DMonitoring_of_ deforestation_and_forest_d.pdf\&X-Amz-Algorithm=AWS4-HMAC-SHA256\&X-Amz-Credential= AKIAIWOWYYGZ2Y53UL3A\%2F20200130\%2Fus-east-1\%2Fs3\%2Faws4_request\&X-Amz-Date= 20200130T055501Z\&X-Amz-Expires=3600\&X-Amz-SignedHeaders=host\&X-Amz-Signature $=$ 77313dbc5b0b67d184a938083b116a87b73bdd2929f6bcdf96b205283ea987b6 (accessed on 30 January 2020).

78. Lunetta, R.S.; Knight, J.F.; Ediriwickrema, J.; Lyon, J.G.; Worthy, L.D. Land-cover change detection using multi-temporal MODIS NDVI data. Remote Sens. Environ. 2006, 105, 142-154. [CrossRef]

79. Manoharan, V.S.; Welch, R.M.; Lawton, R.O. Impact of deforestation on regional surface temperatures and moisture in the Maya lowlands of Guatemala. Geophys. Res. Lett. 2009, 36. [CrossRef]

80. Senay, G.B.; Elliott, R.L. Combining AVHRR-NDVI and landuse data to describe temporal and spatial dynamics of vegetation. For. Ecol. Manag. 2000, 128, 83-91. [CrossRef]

81. Sobrino, J.A.; Julien, Y. Global trends in NDVI-derived parameters obtained from GIMMS data. Int. J. Remote Sens. 2011, 32, 4267-4279. [CrossRef]

82. Van der Werf, G.R.; Morton, D.C.; DeFries, R.S.; Giglio, L.; Randerson, J.T.; Collatz, G.J.; Kasibhatla, P.S. Estimates of fire emissions from an active deforestation region in the southern Amazon based on satellite data and biogeochemical modelling. Biogeosciences 2009, 6, 235-249. [CrossRef]

83. Walsh, S.J.; Crawford, T.W.; Welsh, W.F.; Crews-Meyer, K.A. A multiscale analysis of LULC and NDVI variation in Nang Rong district, northeast Thailand. Agric. Ecosyst. Environ. 2001, 85, 47-64. [CrossRef]

84. Guyton, J.A.; Pansu, J.; Hutchinson, M.C.; Kartzinel, T.R.; Potter, A.B.; Coverdale, T.C.; Daskin, J.H.; da Conceição, A.G.; Peel, M.J.; Stalmans, M.E.; et al. Trophic rewilding revives biotic resistance to shrub invasion. Nat. Ecol. Evol. 2020, 1-13. [CrossRef] [PubMed]

(C) 2020 by the authors. Licensee MDPI, Basel, Switzerland. This article is an open access article distributed under the terms and conditions of the Creative Commons Attribution (CC BY) license (http://creativecommons.org/licenses/by/4.0/). 